University of Miami Law School Institutional Repository

University of Miami Business Law Review

7-1-1999

\title{
The Importance of Compliance Programs for the Health Care Industry
}

Marcos D. Jimenez

Dana Foster

Follow this and additional works at: http://repository.law.miami.edu/umblr

Part of the Health Law and Policy Commons

\section{Recommended Citation}

Marcos D. Jimenez and Dana Foster, The Importance of Compliance Programs for the Health Care Industry, 7 U. Miami Bus. L. Rev. 503 (1999)

Available at: http://repository.law.miami.edu/umblr/vol7/iss3/11

This Article is brought to you for free and open access by Institutional Repository. It has been accepted for inclusion in University of Miami Business Law Review by an authorized administrator of Institutional Repository. For more information, please contact library@law.miami.edu. 


\title{
THE IMPORTANCE OF COMPLIANCE PROGRAMS FOR THE HEALTH CARE INDUSTRY
}

\author{
MARCOS D. JIMÉNEZ* \\ DANA FOSTER **
}

I. INTRODUCTION . . . . . . . . . . . . . . . . . 503

II. Basics of A HEALth CARE Compliance PRogram ......... 504

III. Benefits of A HEalth CARE Compliance Program ....... 508

IV. PRACTICAL EFFECTS AND DIFFICULTIES OF

CorPorate Compliance Program $\ldots \ldots \ldots \ldots \ldots \ldots \ldots . \ldots 11$

\section{INTRODUCTION}

Civil and criminal liability for health care companies and their representatives is a continuing and growing threat. While organized health care fraud (particularly in the Medicare area) is a well-known problem, ${ }^{1}$ legitimate health care organizations increasingly face criminal and civil exposure due to various factors, including increased enforcement of complex federal regulations and improper actions by companies whose representatives are tempted to cut corners due to shrinking margins and increased competition in the industry.

Daily headlines demonstrate this increased scrutiny. For example, on March 31, 1999, both the Miami Herald and the Wall Street Journal reported that Olsten Corp., one of the nation's largest providers of home health care and a manager of several Florida home health agencies owned by Columbia/HCA Healthcare Corp., had reached a \$61 million settlement with the U.S. Department of Justice. The settlement further provided that one of Olsten Corp.'s entities, Kimberly Home Health Care, would plead guilty to Medicare fraud charges. ${ }^{2}$ That same day, the Wall Street Journal reported that federal health care investigators had served a subpoena for Medicare records

* Marcos D. Jiménez is a partner in the Miami office of the law firm of White \& Case LLP. His practice is devoted to complex commercial litigation and white-collar criminal defense. He is also a member of the Board of Trustees of Baptist Health Systems, Inc., a not-for-profit company that controls four South Florida hospitals and other heath care entities.

** B.F.A. 1992, Ohio University; J.D. 1999, University of Miami School of Law. Associate, White \& Case LLP.

1 In 1993, the Attorney General designated Health Care Fraud as a top priority. Since then, Medicare fraud cases have increased each year.

2 Olsten Reaches $\$ 61$ Million Settlement, WALL ST. JoURNAL, Mar. 31, 1999 at B7; Olsten to Settle Inquiries with $\$ 61 M$, MIAMI HERALD, Mar. 31, 1999, at 1C. 
upon Centennial HealthCare Corp. in connection with an investigation of potential improper claims for Medicare payments. Centennial HealthCare Corp.'s stock plummeted immediately by $46 \%$. $^{3}$

Of course, a company's exposure to criminal, civil, and administrative penalties can never be eliminated entirely. It can be substantially reduced, however, through the development and implementation of a compliance program. Such programs have become a requirement of prudent corporate management because the institution and operation of an effective program can prevent violations of the law in the first instance, and if the program's preventative function somehow fails it can reduce the penalties imposed in a criminal, administrative, or civil proceeding. In short, compliance programs are an honest corporation's best hope to prevent violations and to limit exposure if a problem has occurred.

The existence of such a program is an essential component of lenity in the sentencing of organizations under the United States Sentencing Guidelines ("Sentencing Guidelines"). ${ }^{4}$ Further, the Office of Inspector General ("OIG") of the Department of Health and Human Services ("HHS") has announced that it will consider the existence of an effective compliance program that predates any governmental investigation when addressing the appropriateness of administrative penalties. ${ }^{5}$

This article examines three subject areas. First, it presents the basic requirements of an effective health care compliance program. Second, the article reviews the benefits of instituting an effective health care compliance program. Finally, the article examines how corporate compliance programs work in practice.

\section{Basics of a Health Care Compliance Program}

The Sentencing Guidelines set forth seven elements for an effective compliance program: (1) the establishment of standards and procedures that are reasonably capable of reducing the prospect of criminal conduct; (2) the assignment of specific individuals to oversee compliance with such standards and procedures; (3) the exercise of due care so that individuals with a propensity to engage in illegal activities do not have substantial discretionary authority within the organization; (4) the communication of the compliance standards and procedures to all employees/agents; (5) the establishment of systems, such as monitoring, auditing, and reporting systems, that enable the

3 Centennial Health Care Inc. Subpoenaed for Nursing-Home Medicare Records, WALl ST. JOURNAL, Mar. 31, 1999, at B7.

$4 \quad$ See U.S.S.G. \$ 8A1.2.

S OIG's Compliance Program Guidelines for Hospitals, at n.2. 
organization to achieve compliance with its standards; (6) the consistent enforcement of such standards through appropriate disciplinary mechanisms; and (7) appropriate response and preventive mechanisms once an organization discovers a violation. ${ }^{6}$ The Sentencing Guidelines explain that the precise actions necessary for a company to have an effective program depend upon several factors, including: the size of the organization, the likelihood that certain offenses may occur because of the nature of its business, and the prior history of the entity.

In the health care industry, uniform standards and practices for compliance programs for health care organizations as a whole have not arisen due largely to the diversity of the health care industry. The OIG, however, has developed compliance program guidelines for hospitals, ${ }^{7}$ which set forth specific elements that hospitals should consider when developing and implementing a compliance program. ${ }^{8}$ In addition, the OIG has developed a Model Compliance Plan for Clinical Laboratories, which OIG initially released in February 1997 and substantially revised on August 4, 1998. ${ }^{9}$ Recently, the OIG released its Compliance Program for Home Health Agencies, ${ }^{10}$ which, like its predecessors for hospitals and clinical laboratories, is not a compliance program itself, but sets forth guidelines that home health agencies should consider and follow in implementing a compliance program. The OIG has also developed compliance plan guidelines for third party billing companies. ${ }^{11}$ Furthermore, while the federal government has not issued compliance program guidelines for managed care organizations (such as HMOs), the OIG has issued Compliance Program Guidance for the Medicare + Choice program. ${ }^{12}$ Most recently, the OIG published compliance plan guidelines for nursing facilities, hospices, and the durable medical equipment ("DME") industry. ${ }^{13}$ Finally, on September 8, 1999, OIG published a notice

\footnotetext{
See U.S.S.G. § 8 A1.2 (k)(1-7).

The Office of the Inspector General's Compliance Program Guidance for Hospitals, February 1998 ("OIG Compliance Guidance for Hospitals").

8 OIG hastens to add that given the diversity within the industry, there is no single "best" hospital compliance program, and the guidelines are not in and of themselves a compliance program. OIG Compliance Guidance for Hospitals at 4.

Revised Model Compliance Program for Clinical Laboratories, August 4, 1998. Access to the program can be found in the Federal register notices located at www.access.gpo.gov/nara.

10 Publication of the OIG Compliance Program Guidance for Home Health Agencies, 63, No. 152, Fed. Reg. 42,410 (1998) (to be codified at 63 C.F.R. $\$ 42,410$ ).

" OIG Compliance Program Guidelines for Third-Party Medicaid Billing Companies, OIDG website, http://ww.hhs.gov/progorg/OIG/modcomp/thirdparty.htm.

12 OIG Compliance Program Guidance of Medicare + Choice Organizations, ODG website, <http://www.hhs.gov/progorg/OIG/modcomp.>

13 Publication of the Compliance Program Guidance is at the OIDG website, $<$ http://www.hhs.gov/progorg/OIG/modcomp.>
} 
in the Federal Register seeking comment regarding future OIG compliance program guidelines for individual physicians and small group practices. ${ }^{14}$

Obviously, hospitals, clinical laboratories, nursing facilities, hospices, home health agencies, DME companies, and third-party billing companies should carefully consider and incorporate the main elements of existing or future OIG compliance guidelines when crafting or revising their compliance programs. However, all health care organizations should have a compliance program, even if the federal government has not issued compliance program guidelines for their particular area of business. ${ }^{15}$. In developing their compliance programs, these health care organizations should consider the general principles contained in existing OIG compliance program guidelines for other health care organizations such as hospitals and home health agencies, as well as any specific fraud alerts, fraud settlements, and work plans issued by OIG for the type of health care business involved. Health care organizations should also consult industry associations, peer groups, clients, and employees in developing a compliance plan. Of course, the organization should also consult with consultants or other compliance experts. ${ }^{16}$

The OIG guidance for hospitals contains basic elements that all health care organizations should consider, including: the (1) development and distribution of written compliance policies identifying specific areas of risk to the hospital (or health care organization) $;{ }^{17}$ (2) development of standards of conduct for all employees/agents; (3) communication of such policies and standards to all employees/agents and independent contractors affected by them; (4) designation of, and the supervision of the program by, a chief compliance officer and compliance committee; (5) the development of a

14 Id. The OIG has promised to publish similar notices for development of all future compliance guidelines on the OIG's website at http:/www.hhs.gov/progorg/OIG.

is Indeed, recently, on February 1, 1999, Deputy Attomey General Eric H. Holder, Jr., in remarks to the American Hospital Association ("AHA"), suggested that the AHA "take the lead in developing a[n] . . . industry-wide compliance initiative for the health care industry," consistent with the federal government's desire that all healthcare organizations have a compliance program. June Gibbs Brown, the HHS Inspector General, also has proclaimed that, regardless of the type of industry or size of organization, compliance programs should be designed and implemented by all health care providers.

16 A health care organization must recognize and account for the differences between its area of business and relevant laws, on the one hand, and the business of and laws applicable to the types of health care businesses for which the government has developed compliance program guidelines.

17 The OIG has identified 18 risk areas of particular concem for hospitals, including billing for items or services not actually rendered, providing medically unnecessary services, double billing, financial arrangements between hospitals and hospital-based physicians, false cost reports, hospital incentives violating the anti-kickback statute or similar laws, joint ventures and patient dumping. With respect to several of these risk areas, the compliance guidelines for hospitals provide very specific guidance. For example, the guidelines set forth policies and procedures for accurate and proper billing and claims for reimbursement or payment. 
records retention and storage system; (6) incorporation of commitment to compliance as a factor in the evaluation of supervisors and managers; (7) effective training and education of hospital personnel as to compliance standards and applicable laws; (8) development of effective lines of communication between the compliance officer and hospital (or health care organization) personnel; (9) effective disciplinary action for failure to comply with the compliance program's standards of conduct; (10) ongoing evaluation of compliance through auditing and monitoring; and (11) prompt investigation and correction of problems detected through the compliance program.

Regardless of the type of health care organization involved, the hallmark of an effective compliance program is the development of standards and procedures that are reasonably capable of reducing the prospect of criminal conduct. This is the key to developing and tailoring an "effective" compliance program for particular health care organizations. To establish such standards, the drafter of the compliance program must consider the laws applicable to the particular health care organization in question.

Perhaps a good place for the health care practitioner to start this process would be to consider the Health Care Model Compliance Manual developed in October 1997 by NHLAVAAHA, Inc., the entity that resulted from the combination of the National Health Lawyers Association and the American Academy of Healthcare Attorneys of the American Hospital Association. ${ }^{18}$ The Health Care Model Compliance Manual has identified the following laws as potentially applicable to a healthcare organization: (1) the Health Insurance Portability and Accountability Act of 1996 ("HIPAA"); 19 (2) the False Claims Act (31 U.S.C. § 3729); (3) criminal false claims relating to Medicare/ Medicaid (42 U.S.C. $\$ 1320 \mathrm{a}-7 \mathrm{~b}(\mathrm{a})$ ); (3) the Anti-Kickback statute (42 U.S.C. $\$ 1320 \mathrm{a}-7 \mathrm{~b}(\mathrm{~b})$ ); (4) Physician Self-Referral (Stark) prohibitions (42 U.S.C. $\$ 1395 \mathrm{nn}$ ); (5) permissive and mandatory exclusion (42 U.S.C. \$1320a-7); (6) Civil Monetary Penalty Law (42 U.S.C. § 1320a-7a); (8) Payment Suspension (42 C.F.R. \$405.370); and (9) the Racketeer Influenced and Corrupt Organizations Act ("RICO") (18 U.S.C. §1964).

\footnotetext{
18 NHLAAAHA can be contacted through its website, http://www.healthlawyers.org.

19 HIPAA established four programs designed to implement federal fraud enforcement priorities: (1) the Fraud and Abuse Control Program; (2) the Medicare Integrity Program; (3) the Beneficiary Incentive Program; and (4) the Health Care Fraud and Abuse Data Collection Program. 29 C.F.R. 2590.736. HIPPA created several new criminal offenses, including healthcare fraud (18 U.S.C. 81347), embezzlement of healthcare funds (18 U.S.C. \$669) and false statements relating to healthcare (18 U.S.C. \$1035). HIPPA also significantly modified the Civil Monetary Penalties Law, 42 U.S.C. \$1320a-7a, adding new prohibited practices, including: (1) engaging in a pattern of upcoding; and (2) engaging in a pattern of claiming medically unnecessary services, among others.
} 


\section{Benefits of a Health Care Complince Program}

The Guidelines incentivize companies to establish corporate compliance and monitoring systems. Furthermore, the dangers posed by inadequate compliance procedures serve as additional motivation for companies to police themselves.

A corporation's failure to institute a compliance program may constitute a breach of the corporation's (or its directors') fiduciary obligations. In In re Caremark International Inc. Derivative Litigation ${ }^{20}$ shareholders of Caremark brought a lawsuit against the corporation to recover damages as a result of the corporation's fraudulent activities, which caused losses to the corporation and diminished the value of its shares. In discussing the directors' liability for failure to monitor the functions of the corporation, the Caremark court stated that a corporation should assure itself that information and reporting systems in the form of corporate compliance plans are in place so the directors can reach informed judgments about the entity's compliance with law and its business performance.

In suggesting a legal duty to have a corporate compliance plan in place for health care providers, the court noted that the level of detail of the plan is a question for business judgment. The court ultimately held that the failure to implement a compliance program could render a director liable for losses caused by the noncompliance with applicable legal standards. The Caremark case instructs that a professional health care Corporation has a legal duty to implement a compliance plan and could be liable to shareholders for any losses that result from the absence of a compliance plan. Thus, after Caremark, health care corporations have even greater incentives to ensure that they establish and maintain adequate compliance and oversight programs. Under the reasoning of Caremark and the Sentencing Guidelines, the presence or absence of a comprehensive compliance program can have a profound effect on a corporation's or its directors' liability in both civil and criminal Cases.

The benefits of effective programs have been heralded many times: they set a positive corporate tone, they deter employee misconduct, they help insulate corporate officers and directors from civil liability, they can substantially reduce a company's fine in the event of a criminal conviction and perhaps the ultimate benefit is that they can provide defense counsel with powerful ammunition to persuade prosecutors or regulators to decline to file charges. In the style of David Letterman, Lewis Morris, the Assistant 
Inspector General for Legal Affairs of HHS recently prepared a document entitled "Top 10 Reasons to Implement a Compliance Program." The "Top 10 " according to Morris are:

1. Adopting a compliance program concretely demonstrates to the community at large that a provider has a strong commitment to honesty and responsible corporate citizenship.

2. Compliance programs reinforce employees' innate sense of right and wrong.

3. An effective compliance program helps a provider fulfill its legal duty to government and private payors.

4. Compliance programs are cost-effective.

5. A compliance program provides a more accurate view of employee and contractor behavior relating to fraud and abuse.

6. The quality of care provided to patients is enhanced by an effective compliance program.

7. A compliance program provides procedures to promptly correct misconduct.

8. An effective compliance program may mitigate any sanctions imposed by the Government.

9. Voluntarily implementing a compliance program is preferable to waiting for the OIG to impose a corporate integrity agreement.

10. Effective corporate compliance programs may protect corporate directors from personal liability.

Certainly, implementation of an effective compliance program produces immediate benefits, including:

(1) Prevention of Misconduct. A strong compliance program serves to detect and provide early warnings before misconduct develops into a criminal violation. Preventing even one criminal violation would likely cover the costs of the compliance program. Moreover, regardless of the outcome of a criminal investigation, the cost of retaining defense counsel can be very significant. In the blunt words of a general counsel of a major corporation, "any company that thinks it has no realistic chance of criminal indictment is living in a fantasy world." 21 
(2) Effect on Prosecutorial Decisions. It is naive to expect that a compliance program will prevent all violations. However, if a company has in good faith tried to meet applicable legal standards and exercised due diligence to prevent violations, it may well be able to make a convincing argument to prosecutors that it should be spared prosecution. An effective compliance program helps convince prosecutors that there are other candidates in the business world who are more appropriate targets for prosecutorial guns.

(3) Penalty Mitigation. Under the Sentencing Guidelines, a company can receive benefits as a result of its effective compliance program. If the company discloses any violations upon discovery and cooperates with the prosecution, the company may earn a substantial reduction of any fine. In the event of civil litigation, a company may be able to convince a judge or jury that it is a responsible corporate citizen that should not feel the lash of either compensatory or punitive damages.

(4) Avoidance of Imposed Compliance Plans. A company with no compliance program invites the court to impose one as a condition of probation in any criminal case. It also invites OIG to impose one as part of a corporate integrity agreement, which OIG will require from companies wishing to avoid exclusion from federal health care programs. A company should not have to face the prospect of supervision by an appointed probation officer, or OIG, in the development and implementation of the program.

(5) Reputation. A well-designed and effective compliance program can have benefits outside the legal system. Having a reputation as fair and honest can enhance employee morale and aid in recruiting the brightest and best employees.

In addition to the above listed benefits, a hospital may gain numerous additional benefits by implementing an effective compliance program. Such programs make good business sense in that they help a hospital fulfill its fundamental care-giving mission to patients and the community, and assist hospitals in identifying weaknesses in internal systems and management. Other important benefits include the ability to: (1) demonstrate to employees and the community the hospital's strong commitment to be an honest and 
responsible provider; (2) provide a more accurate view of employee and contractor fraud and abuse; (3) help personnel make sound decisions; (4) tailor a compliance program to the hospital's specific needs; (5) improve the quality of patient care; (6) create a centralized source for distributing information on health care statutes, regulations, and other fraud and abuse issues including changes in government requirements; (7) encourage employees to report potential problems and concerns internally, rather than externally, which may reduce government investigations; (8) implement procedures to allow prompt investigation of alleged misconduct by corporate officers, managers, employees, independent contractors, physicians and consultants; and (9) initiate appropriate and immediate corrective action. ${ }^{22}$

\section{Practical EFfects and Difficulties of CoRporate Compliance Program}

Notwithstanding the clear benefits of compliance programs, many big and small companies face recurring problems in implementing them. These problems often surface during regulatory and prosecutorial investigations involving alleged corporate misconduct. Once a compliance program has been established, practical difficulties with respect to voluntary disclosure may arise. Additionally, some complain that compliance officers have been forced into roles akin to an independent counsel within the corporation, pledging their loyalty not to the corporation but to government enforcement agencies. As a further difficulty, many are concerned that information learned by compliance officers is not protected by the attorney-client privilege, thus preventing the informed and knowing disclosures that privilege protection affords.

Some other real-world problems which can plague a company include: (1) the chief compliance officer failing to regularly communicate with the board of directors; (2) the company undergoing a merger or acquisition and failing to revise its policies to reflect the new entity or entities, or their compliance needs; (3) discipline not being uniformly enforced; (4) in drafting a code of conduct and compliance policies, the 'borrowing' of a compliance template from another company and 'cutting and pasting' a new policy; (5) the company failing to document its compliance program efforts; (6) the company's failure to record that employees have received training and read the code of conduct and compliance policies; and (7) company failure to regularly re-evaluate and revise the compliance program. 
Regardless of the problems in creating and implementing an effective compliance program, it is important not to wait to develop a compliance plan until it is too late. Under the Sentencing Guidelines, the courts can require companies that do not have an effective compliance program to craft and implement one as part of their sentence. The sentencing phase of a criminal case is not the ideal time to create a compliance program, particularly if your company is under the watchful eye of a compliance monitor and has to pay a substantial fine. In addition, on the civil and administrative side, the OIG may require a health care provider to establish a corporate integrity plan, usually following an investigation or audit, that may last for years under the oversight of the OIG. ${ }^{23}$ Failure to adhere to a corporate integrity plan may result in exclusion of the provider.

It is essential that providers institute an effective corporate compliance program that establishes the company's ethical and legal policies and the compliance standards that are expected from all employees. Today an effective corporate compliance program is the industry standard. Any health care provider that operates below industry standards will lose its competitive edge and will expose itself to substantial penalties.

23 According to a recent Semiannual Report of the OIG, for the period from April 1, 1998 to September 30,1998, OIG reported 3,021 exclusions of individuals and entities for fraud or abuse of the federal health care programs and/or their beneficiaries, 261 convictions of individuals or entities that engaged in crimes against departmental programs, and 927 civil actions. 